\title{
Di-(2 ethylhexyl) phthalate and flutamide alter gene expression in the testis of immature male rats

\author{
Thuy TB Vo ${ }^{\dagger 1}$, Eui-Man Jung ${ }^{\dagger 1}$, Vu Hoang Dang ${ }^{1}$, Yeong-Min Yoo ${ }^{1}$, Kyung- \\ Chul Choi ${ }^{1}$, Frank $\mathrm{H} \mathrm{Yu}^{2}$ and Eui-Bae Jeung*1
}

\author{
Address: ${ }^{1}$ Laboratory of Veterinary Biochemistry and Molecular Biology, College of Veterinary Medicine, Chungbuk National University, \\ Cheongju, Chungbuk, 361-763, Republic of Korea and ${ }^{2}$ School of Dentistry, Seoul National University, Seoul, 110-768, Republic of Korea \\ Email: Thuy TB Vo - thuynvdc@yahoo.com; Eui-Man Jung - jemman@hanmail.net; Vu Hoang Dang - dangnivr@yahoo.com; Yeong- \\ Min Yoo - yyeongm@hanmail.net; Kyung-Chul Choi - kchoi@cbu.ac.kr; Frank H Yu - frankyu@snu.ac.kr; Eui- \\ Bae Jeung* - ebjeung@chungbuk.ac.kr \\ * Corresponding author †Equal contributors
}

Published: 26 September 2009

Reproductive Biology and Endocrinology 2009, 7:104

doi:10.1186/1477-7827-7-104

This article is available from: http://www.rbej.com/content/7/I/104

(c) 2009 Vo et al; licensee BioMed Central Ltd.

This is an Open Access article distributed under the terms of the Creative Commons Attribution License (http://creativecommons.org/licenses/by/2.0), which permits unrestricted use, distribution, and reproduction in any medium, provided the original work is properly cited.

\begin{abstract}
We previously demonstrated that the androgenic and anti-androgenic effects of endocrine disruptors (EDs) alter reproductive function and exert distinct effects on developing male reproductive organs. To further investigate these effects, we used an immature rat model to examine the effects of di-(2 ethylhexyl) phthalate (DEHP) and flutamide (Flu) on the male reproductive system. Immature male SD rats were treated daily with DEHP and Flu on postnatal days (PNDs) 2 I to 35, in a dose-dependent manner. As results, the weights of the testes, prostate, and seminal vesicle and anogenital distances (AGD) decreased significantly in response to high doses of DEHP or Flu. Testosterone $(T)$ levels significantly decreased in all DEHP- treated groups, whereas luteinizing hormone $(\mathrm{LH})$ plasma levels were not altered by any of the two treatments at PND 36. However, treatment with DEHP or Flu induced histopathological changes in the testes, wherein degeneration and disorders of Leydig cells, germ cells and dilatation of tubular lumen were observed in a dose-dependent manner. Conversely, hyperplasia and denseness of Leydig, Sertoli and germ cells were observed in rats given with high doses of Flu. The results by CDNA microarray analysis indicated that I,272 genes were up-regulated by more than two-fold, and I,969 genes were down-regulated in response to DEHP, Flu or both EDs. These genes were selected based on their markedly increased or decreased expression levels. These genes have been also classified on the basis of gene ontology (e.g., steroid hormone biosynthetic process, regulation of transcription, signal transduction, metabolic process, biosynthetic process...). Significant decreases in gene expression were observed in steroidogenic genes (i.e., Star, Cypl la l and Hsd3b). In addition, the expression of a common set of target genes, including CaBPI, Vav2, PlcdI, LhxI and Isocl, was altered following exposure to EDs, suggesting that they may be marker genes to screen for the antiandrogenic or androgenic effects of EDs. Overall, our results demonstrated that exposure to DEHP, Flu or both EDs resulted in a alteration of gene expression in the testes of immature male rats. Furthermore, the toxicological effects of these EDs on the male reproductive system resulted from their anti-androgenic effects. Taken together, these results provide a new insight into the molecular mechanisms underlying the detrimental impacts of EDs, in regards to anti-androgenic effects in humans and wildlife.
\end{abstract}




\section{Background}

Over the past two decades, the detrimental effects of endocrine disruptors (EDs) on wildlife and humans have become a major public health concern. Endocrine disruptors, a large group of environmental pollutants, are believed to act as agonists or antagonists of androgens and estrogens, which are key hormones involved in many physiological processes. These pollutants have been linked to male reproductive defects in humans, including an increase in the incidence of testicular cancer [1], and declining semen quality [2]. Evidence of cryptorchidism, undescended testis and hypospadias have also been demonstrated [3]. In addition, EDs have been linked to developmental problems in the testis and reproductive tract, including reductions in fertility and litter size, induction of cryptorchidism and testicular atrophy [4,5].

Normal development of the male reproductive tract requires interactions between many biological factors and hormones. In particular, androgen hormones are essential to this process. However, many environmental chemicals have androgenic or anti-androgenic effects, or can mimic androgenic activities (i.e., thereby stimulating an androgen-dependent response). Adverse trends in human and animal male reproductive health, particularly with regards to the regulation of environmental factors, suggest that future generations will be at greater risk. Previous reports have suggested that male reproductive system disorders, which often originate during the fetal stage, can appear as testicular dysgenesis syndrome (TDS) after birth [6].

Previous studies demonstrated the possible effects of antiandrogenic- EDs [i.e., flutamide and/or di- (2 ethylhexyl) phthalate] on the reduction of androgen synthesis during the development of the male reproductive tract $[7,8]$. These EDs appear to induce abnormalities in the formation of external genitalia, i.e., hypospadias, cryptorchidism and agenesis of the epididymis, vas deferens and prostate. In additional, the effects of these EDs were also observed with regards to AGD and nipple retention [5]. In humans, some of these alterations are permanent and affect testes function later in life [9]. Although EDinduced harmful effects on male reproduction have been demonstrated, the molecular mechanisms by which EDs disrupt testis development and affect testicular dysgenesis are not clearly understood.

Di-ethylhexyl phthalate (DEHP) is widely used as a plasticizer in commercial products [10]. The effects of DEHP on male reproductive development have been well studied in rats [11]. In addition, phthalates and their metabolites can be released from such products and have been detected in the environment [12], posing potential health risks for humans and wildlife. Infants may be exposed to phthalates in the womb [13], via breastfeeding [14] or from medical devices in neonatal intensive care units [15]. Although DEHP has been reported to modulate fetal testosterone production [16], testicular physiology, and mammalian reproduction and fertility [17], the exact mechanisms by which DEHP exerts detrimental effects on body have not yet been fully elucidated. Previous studies have demonstrated the adverse effects of DEHP on the hypothalamic-pituitary-gonadal axis in neonatal female rats, as well as on ex vivo steroidogenesis in granulosa cells (GCs) and secretion of LH by gonadotropes [18]. Moreover, exposure to phthalates during reproductive tract development reduces the number of Sertoli cells (i.e., the major somatic cell type, which supports spermatogenesis) [19]. In addition, DEHP and its metabolites decrease testicular testosterone levels in rodents [20], suggesting potential impacts of these contaminants on Leydig cells. A recent study has indicated that a variety of steroidogenesis related genes were altered following phthalate- exposure and a down-regulation of most of genes involved in testosterone (T) biosynthetic pathways was observed, indicating the potential mechanism for decreased $\mathrm{T}$ synthesis induced by phthalate exposure [21]. Other study has reported a similar genetic response in the fetal and prepubertal testes of rats exposed to these environmental chemicals [22].

Flutamide (Flu) is a well-known AR antagonist that is widely used in therapies for androgen-dependent prostate cancer [23] Pre- and postnatal exposure of rats to Flu alters androgen-dependent reproductive development and function [24]. Flu exposure also increases plasma LH levels and stimulates intracellular steroidogenesis in rat testes. In addition, lower ventral prostate and seminal vesicle weights have also been reported, suggesting that Flu exerts anti-androgenic effects on androgen-targeting organs [25]. It has been indicated that exposure of rats to Flu caused a dysregulation in expression of hypothalamus/ pituitary hormone genes and consequently this may affect gonadotropin release and induce an over-expression of testicular steroidogenic enzyme genes [26].

In this study, we used an immature rat model of development to examine the adverse effects of DEHP and Flu on the male reproductive system. In particular, we examined the effects of DEHP and Flu on the male reproductive tract and the production of testosterone and $\mathrm{LH}$. We also assessed the histopathological changes of the testis in response to ED exposure. AGD values were used as androgen-dependent markers to assess the anti-androgenic and androgenic activities of the EDs. In addition, we examined alterations in gene expression in the testis of immature rats following DEHP or Flu treatment. Testosterone propionate (TP), an androgen agonist, was used as an indication of androgenic activity in androgen-responsive organs. Our findings will contribute to a better under- 
standing of the detrimental effects of anti-androgenic EDs on humans and wildlife.

\section{Methods}

\section{Chemicals}

Testosterone propionate (TP; \# 203-08433) and di-(2-ethlhexyl) phthalate (DEHP; \# 80032) were purchased from the Wako Chemical Company (Osaka, Japan). Flutamide (Flu; \# F-9397) and corn oil (i.e., used as a vehicle) were obtained from Sigma-Aldrich Ltd. (St Louis, MO, USA).

\section{Animals and treatment}

Sprague-Dawley (SD; 32 males) immature rats were purchased from SamTaKo-Bio Korea (Chungbuk, Korea). The rats were housed in polycarbonate cages in a controlled environment, with an illumination schedule of 12 hour light/12 hour dark. Rats were fed a diet of soy-free pellets (Samyang Ltd., Korea), and water was provided ad libitum. All experimental procedures, including those involving animals, were approved by the ethics committee of Chungbuk National University. From postnatal days (PNDs) 21 to 35, rats were treated daily with TP $(1 \mathrm{mg} / \mathrm{kg}$ body weight $[\mathrm{BW}] /$ day $),$ DEHP $(10,100$ or $500 \mathrm{mg} / \mathrm{kg}$ $\mathrm{BW} /$ day), Flu (1, 10 or $50 \mathrm{mg} / \mathrm{kg} \mathrm{BW/day)} \mathrm{via} \mathrm{oral} \mathrm{gavage}$ or with corn oil ( $5 \mathrm{ml} / \mathrm{kg} \mathrm{BW/day)}$ as a vehicle. Dosages were adjusted according to changes in body weight. Body weights, clinical signs and abnormal behaviors were recorded daily throughout the experimental periods. All animals were euthanized by exposure to ethyl ether 24 hours after the final treatment. Blood was collected from the descending vena cava and serum was prepared for hormonal analysis. Changes in the weights of testes, epididymides, prostate and seminal vesicles were recorded. Four testes were collected from each group for total RNA isolation. Other testes were fixed in Bouin's solution, paraffin embedded, and sectioned at $5 \mu \mathrm{m}$ for histopathological examination.

\section{Hormonal measurements}

After collecting blood from the abdominal aorta, serum was prepared and stored at $-20^{\circ} \mathrm{C}$ for testosterone and $\mathrm{LH}$ analyses. The Testosterone Enzyme Immunoassay kit (No. 900-065) was obtained from Assay Designs, Inc (Ann Arbor, USA) and the LH Detect Kit was purchased from INRA (Nouzilly, France). ELISA tests were performed according to the manufacturer's recommendations. The coefficients of variation (CV) of intra- and inter-assays were $4 \%$ and $14 \%$.

\section{Total RNA preparation}

Total RNA was extracted from the testes of immature male rats using Trizol (Invitrogen, Carlsbad, CA, USA), according to the manufacturer's recommendations. To make cDNAs from mRNAs for microarray analysis, the same quantity of each RNA sample from the treated groups or control group was pooled. The concentration and quality of each RNA sample was determined by measuring absorbances at $260 \mathrm{~nm}$ and $280 \mathrm{~nm}$.

\section{cDNA microarray analysis of testes}

The oligo chip of GeneChip ${ }^{\circledast}$ Rat Genome 2302.0 Array (Affymetrix, CA, USA), containing over 31,000 probe sets and representing over 28,000 well-substantiated rat genes, were used according to the supplier's instructions. Briefly, total RNA (i.e., $30 \mu \mathrm{g}$ ) from each testis was converted to cDNA for use for microarray analyses. The cDNA products were subsequently subjected to in vitro transcription using biotinylated cytidine 5 '-triphosphate and uridine-5'-triphosphate. Fluorescent labels were incorporated during reverse-transcription of pooled poly (A)+ RNA from the testes of animals in the DEHP, Flu or control groups, after priming with oligo (dT) primers (Ambion, Austin, TX). Four replicates per group were used for hybridization, thus all together 12 microarrays ( 3 groups $\times 4$ biological replicates) were employed to evaluate gene alteration by EDs in this study. The fluorescent targets (i.e., Cy3-dCTP controls and Cy5-dCTP experimental cDNAs) were mixed, added to the microarray surface and covered with a cover slip. After overnight incubation at $65^{\circ} \mathrm{C}$ in a humidified environment, microchips were washed and scanned using a GeneChip Scanner 3000 (Affymatrix, Inc, CA, USA). Quantitative values for signals were calculated using GenePix Pro software, version 5.1 (Molecular Devices Co., CA, USA). Data analysis was performed using the GenePlex (Istech, Inc., Korea). Logged gene expression ratios were normalized by LOWESS (Locally weighted scatter plot smoother) regression as previously described [27]. The biological pathways of the genes were classified based on pathway analysis in which the classification of pathway of interesting genes was determined based on Database for Annotation Visualization and Integrated Discovery (DAVID) http://david.abcc.ncifcrf.gov/.

The statistical significance of microarray gene expression was assessed by computing a q-value for each gene. To determine the q-value, we used a permutation procedure, and for each permutation a two-sample $t$-statistic was computed for each gene. The result was considered significant when the logarithmic gene expression ratio of four independent hybridizations was more than twofold the difference in the expression level. The accuracy of microarray analysis in this study was confirmed by real-time PCR as previously done [28].

\section{Real-time PCR analysis}

The results of cDNA microarray analyses were confirmed and validated via real-time PCR. The primers sequences used in real-time PCR analysis are described in Table 1. Samples were analyzed in a $20 \mu \mathrm{l}$ reaction volume containing $10 \mu \mathrm{l}$ of SYBR premix Ex Taq (TaKaRa Bio., Inc.) 
Table I: Primer sequences for Real-time PCR analyses of gene expression

\begin{tabular}{|c|c|c|c|c|}
\hline Transcript ID & Gene Symbol & & Sequense (5'-3') & Size \\
\hline NM_03I558 & StAR & $\begin{array}{l}\text { Forward } \\
\text { Reverse }\end{array}$ & $\begin{array}{l}\text { tcaaggaatcaaggtcctg } \\
\text { tgttcagctctgatgacacc }\end{array}$ & 208 \\
\hline NM_017286 & Cypllal & $\begin{array}{l}\text { Forward } \\
\text { Reverse }\end{array}$ & $\begin{array}{l}\text { Atccagcttctttcccaatc } \\
\text { caggatgaggttgaacttgg }\end{array}$ & 229 \\
\hline NM_017265 & $H S D 3 b$ & $\begin{array}{l}\text { Forward } \\
\text { Reverse }\end{array}$ & $\begin{array}{l}\text { Cgctgctgtcattgatgtct } \\
\text { tatgcagtgtgccaccattt }\end{array}$ & 299 \\
\hline NM_133529 & Cabpl & $\begin{array}{l}\text { Forward } \\
\text { Reverse }\end{array}$ & $\begin{array}{l}\text { tgactttgtggaactgatgg } \\
\text { gaagtccactcgtccatctc }\end{array}$ & 232 \\
\hline XM_216030 & Vav2 & $\begin{array}{l}\text { Forward } \\
\text { Reverse }\end{array}$ & $\begin{array}{l}\text { cagaggagacggctgaaaac } \\
\text { gatgaggtcctccaggttga }\end{array}$ & 338 \\
\hline NM_I45880 & Lhxl & $\begin{array}{l}\text { Forward } \\
\text { Reverse }\end{array}$ & $\begin{array}{l}\text { Ttctggaccgtttcctcttg } \\
\text { gaaccagatcgcttggagag }\end{array}$ & 198 \\
\hline NM_00I0I4242 & Isocl & $\begin{array}{l}\text { Forward } \\
\text { Reverse }\end{array}$ & $\begin{array}{l}\text { acacgtctgtatccagcaga } \\
\text { Tggccttaattaggttctgg }\end{array}$ & 227 \\
\hline NM_017035 & Plcdl & $\begin{array}{l}\text { Forward } \\
\text { Reverse }\end{array}$ & $\begin{array}{l}\text { agctgccaaaggtcaataag } \\
\text { ctctggccaataaagtcgtt }\end{array}$ & 238 \\
\hline
\end{tabular}

using a 7300 Real-Time PCR system (Applied Biosystems, Foster, CA, USA), following the manufacturer's recommendations. The relative expression level of each gene was normalized to that of HPRT (i.e., an internal control gene) and quantified using RQ software (Applied Biosystems).

\section{Histopathological examination of testis}

Testis tissues were fixed in Bouin's solution and immersed in neutral formalin solution. The fixed tissues were embedded in paraffin, sectioned at $5 \mu \mathrm{m}$ and mounted on slides. These sections were stained with hematoxylin and eosin (H\&E), and histopathological changes were examined under a light microscope.

\section{Statistical analyses}

Results are presented as means \pm standard deviations (SD). Absolute body weights, sexual organ weights and AGD measurements were analyzed at the time of necropsy. When significant changes were detected, Tukey's multiple regression test was used to compare the treatments (i.e., by comparing the control and experimental groups). Data were considered statistically significant at $p<0.05$.

\section{Results \\ Effects of DEHP and Flu on body weight, reproductive organ weight and anogenital distances}

Exposure of immature male rats to DEHP or Flu did not cause any significant changes in body weight (Figure 1A). However, a high doses of DEHP (i.e., $500 \mathrm{mg} / \mathrm{kg} \mathrm{BW/day)}$ or Flu (i.e., $50 \mathrm{mg} / \mathrm{kg} \mathrm{BW/day)} \mathrm{significantly} \mathrm{decreased} \mathrm{the}$ weights of reproductive organs (e.g. testis, prostate and seminal vehicle weights) as shown in Figure 1. Interestingly, the diminution of epididymis weight was detected in a smaller dose of DEHP and all doses of Flu treatment group. As expected, the high doses of DEHP and Flu sig- nificantly decreased AGD when compared with a vehicle, demonstrating the potential effects of DEHP or Flu on androgen-responsive organs (Figure 1F). However, any significant effect in the androgen- dependent organs in animals treated with TP was not observed even though there is a tendency of gene alterations by TP as seen Figure 1. These results suggest that androgens have been linked with alterations in several end points measured in the immature male onset assay, but seem likely that higher doses of TP may cause this.

\section{Effects of DEHP and Flu on serum concentrations of testosterone and $\mathbf{L H}$}

To further explore the effects of DEHP and Flu on critical stages in the development of the male reproductive system, serum concentrations of testosterone and LH were measured using an ELISA kit. As shown in Figure 2, a significant decrease in the levels of testosterone was observed when rats were exposed to all doses of DEHP (i.e., 10, $100,500 \mathrm{mg} / \mathrm{kg} \mathrm{BW} /$ day). However, no significant alteration by any of the two treatments was observed in the serum levels of $\mathrm{LH}$, although these compounds showed a tendency to decrease LH levels. TP treatment as an androgen agonist increased the circulating testosterone without affecting the levels of LH. These data suggest that DEHP exerts an effect on the circulating levels of testosterone in immature male rats.

\section{Effects of DEHP and Flu on histopathology of the testes}

Histopathological abnormalities in the testes of immature male rats exposed to DEHP and Flu were examined by hematoxylin and eosin (H\&E) staining, as described in the Materials and Methods. Testes are androgen-responsive tissues; thus, alterations in the morphology and histology of testes can result from the anti-androgenic effects of chemicals. As seen in Figure 3 and 4, testes morphology 
A

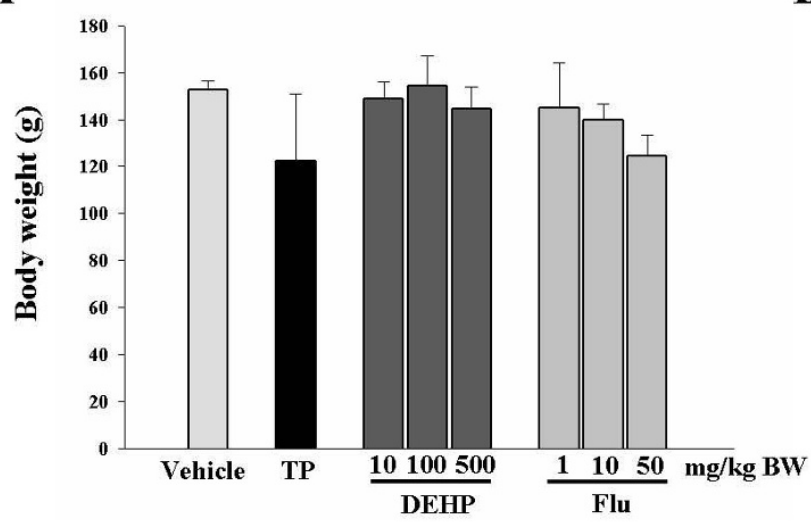

C

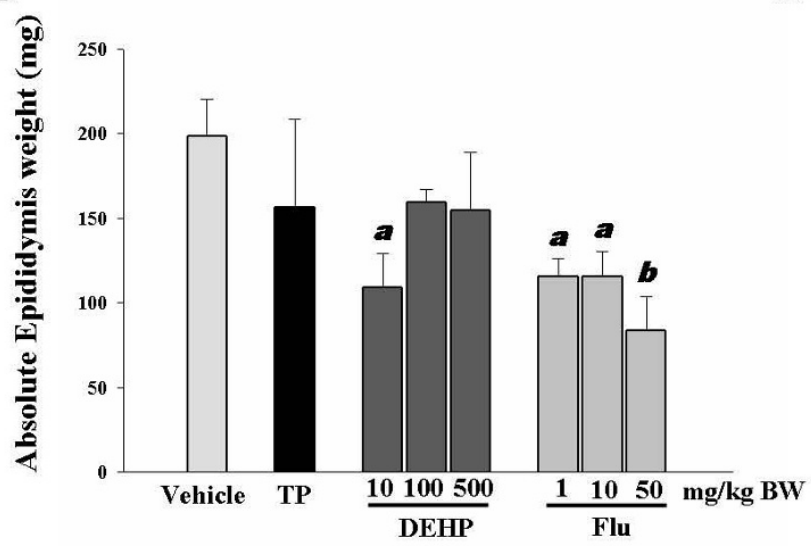

$\mathbf{E}$

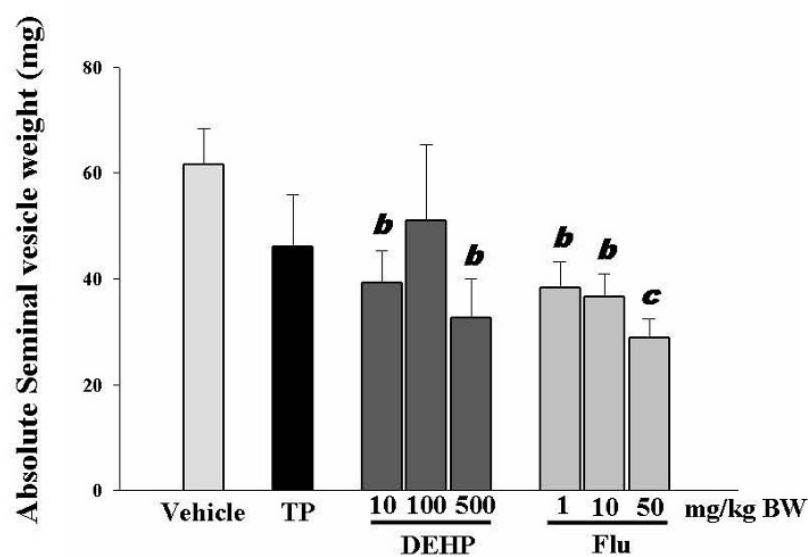

$\mathbf{F}$
B

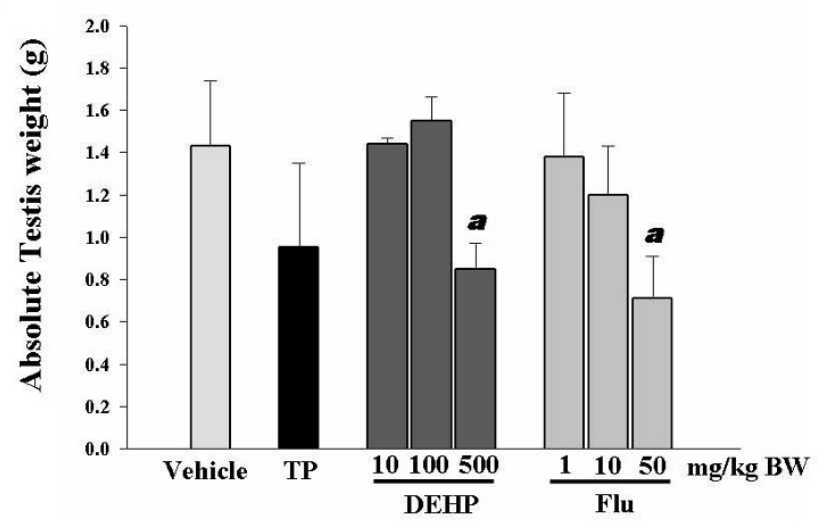

D
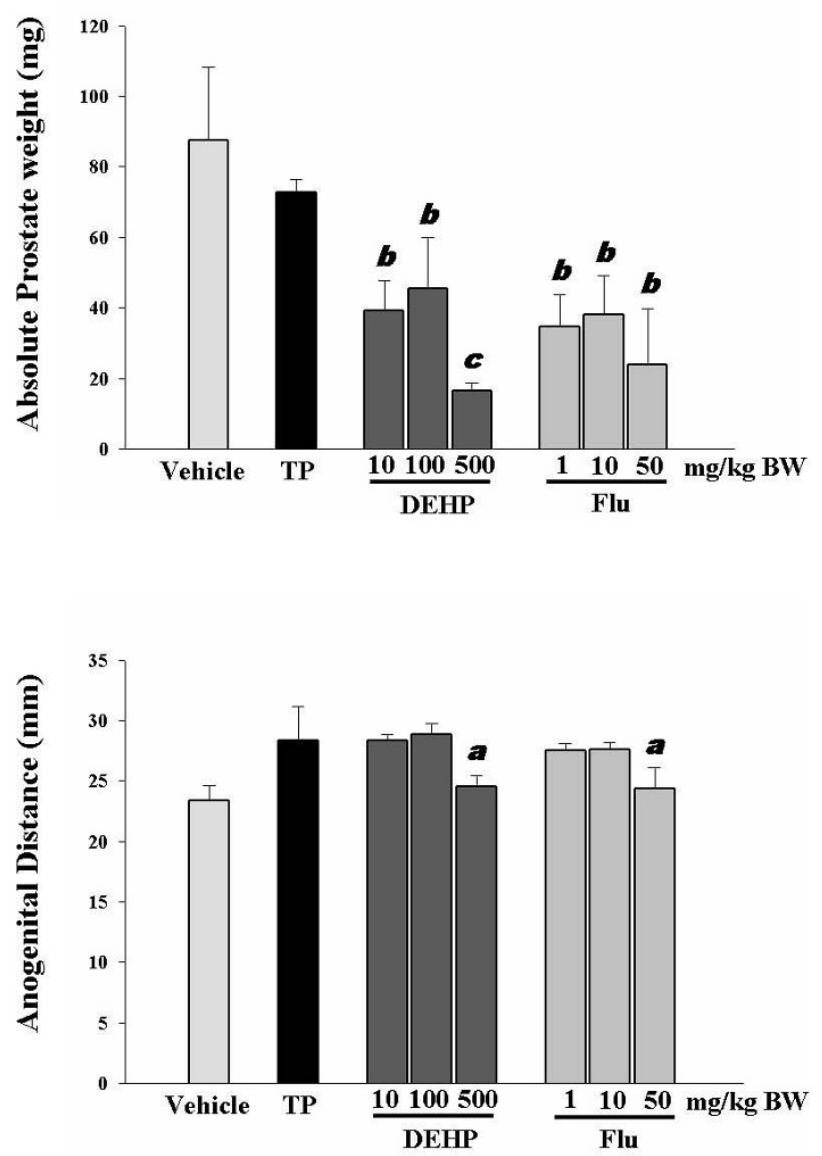

Figure I

Effects of TP, DEHP and Flu on body weight, reproductive organ weight, and anogenital distance in immature male rats $(n=4 /$ group $)$. The weights of testes, epididymis, prostate and seminal vesicles were recorded. Data were analyzed by ANOVA, followed by Tukey's multiple regression. $\mathrm{a}$ : $\mathrm{p}<0.05$; $\mathrm{b}$ : $\mathrm{p}<0.0 \mathrm{l}$ and $\mathrm{c}$ : $\mathrm{p}<0.00 \mathrm{I}$, compared with a control.

and histology were influenced by treatment with DEHP and Flu, respectively. Degeneration of Leydig cells and disorders of germ cells in the reproductive tract were noted in response to all doses of DEHP and Flu. In addition, dila- tation of the tubular lumen and stratification of germ cells were observed when rats were treated with DEHP (i.e., 100 and $500 \mathrm{mg} / \mathrm{kg} \mathrm{BW/day)} \mathrm{(Figure} 3$ and 4). Hyperplasia of Leydig and Sertoli cells appeared in rat testes at PND 
A

\section{B}
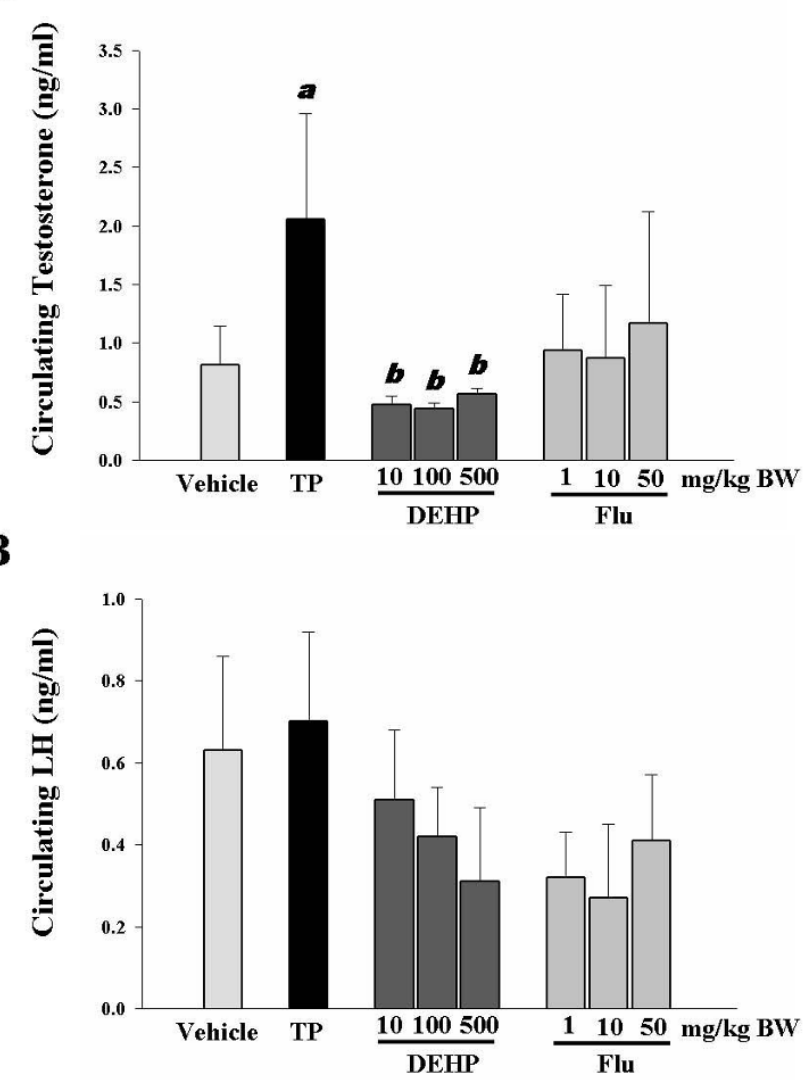

Figure 2

Effects of TP, DEHP and Flu on circulating testosterone and LH levels in immature male rats. A. Serum testosterone concentration. B. Serum $\mathrm{LH}$ concentrations were altered by ED exposure (i.e., $n=4$ ). Data are shown as mean \pm SEM. Significant differences were noted relative to a control (i.e., a, p < 0.05 ) or TP (i.e., b, p < 0.05).

36 in response to high doses of Flu (i.e., $50 \mathrm{mg} / \mathrm{kg}$ BW/ day) (Figure 4). In addition, widespread germ cells disorder or leydig cells degeneration resulted from treatment with all dose of DEHP and Flu (Figure 3 and 4). These results demonstrate the adverse effects of anti-androgenic EDs on the male reproductive tract, particularly with regards to spermatogenesis.

Effects of DEHP and Flu on gene expression in the testes Gene expression in immature rat testes in response to TP, DEHP or Flu was assessed using cDNA microarrays. In total, 37,317 of 41,016 genes were dysregulated following treatment with DEHP (i.e., $100 \mathrm{mg}$ ) or Flu (i.e., $10 \mathrm{mg}$ ), when compared with a control. Among these genes, 1,272 genes were up-regulated over 2-fold change and 1,969 genes were downregulated by more than two-fold. Specific genes were then selected as marker genes for androgenic or anti-androgenic activities of TP, DEHP, or Flu
(Table 2 and 3), respectively, including Orc4l, Mgat4a, and predicted Scrt1, Tmem93, RGD1308066, Omp, RGD1561053, Cnot3, Ubxd6, RGD1561121, Olr297 and Cilp genes. Altered genes have been also classified on the basis of gene ontology (e.g., steroid hormone biosynthetic process, regulation of transcription, signal transduction, metabolic process, catabolic process, biosynthetic process, and integral to membrane, mitochondrion and others) as shown in Table 4. However, the biological interactions of these proteins in response to EDs (i.e., particularly DEHP and Flu) remains unknown. Six genes (i.e., CaBP1, Vav2, Plcd1,Lhx1,Hsd3b and Isoc1) were randomly selected to validate the CDNA microarray results via real-time PCR (Figure 5). The results of these analyses suggest that these genes may be useful markers to screen for anti-androgenic effects of EDs in androgen-responsive tissues. In addition, two well-known marker genes (i.e., StAR and Cyp11a1) were used to screen for the anti-androgenic effects of these EDs. As expected, the expressions of steroidogenesisrelated genes (i.e., StAR and Cyp11a1) were significantly affected by Flu exposure (i.e., $50 \mathrm{mg} / \mathrm{kg}$ BW/day) (Figures $5 \mathrm{~A}$ and $5 \mathrm{~B})$. To confirm the correlation between microarray data and real-time PCR, we plotted the fold changes (versus vehicle) of microarray and real-time PCR results. There was a good correlation between the results obtained from microarray and real-time PCR $\left(\mathrm{R}^{2}=0.824722106, p\right.$ $<0.0001)$. Taken together, these results suggest that exposure to DEHP and Flu resulted in an alteration of gene expression in the testis of immature male rats. The distinct transcriptional response to DEHP and Flu reflect that these EDs may exert their anti-androgenic effects via different mechanisms.

\section{Discussion}

There are a number of mechanisms by which EDs may alter the action of the endocrine system and interfere with the reproduction of humans and animals. Previous studies have shown that EDs mimic the actions of natural hormones and can stimulate or inhibit various enzymes required for hormone synthesis. Consequently, EDs interfere with the regulation of gene expression, disrupting the natural hormone balance and interfering with the normal action of the reproductive system. In particular, EDs may exert distinct androgenic and anti-androgenic effects on the developing male reproductive system in utero [29]. Although previous studies have examined the effects of these chemicals on critical stages in the development of the male reproductive system, the relationship between molecular events and detrimental effects of these EDs is not well described. To further explore these effects, we used an immature rat model of development to examine the adverse effects of DEHP and Flu on the male reproductive system. Oral treatments with DEHP (i.e., 10, 100 and $500 \mathrm{mg} / \mathrm{kg} \mathrm{BW} /$ day) and Flu (i.e., 1, 10 and $50 \mathrm{mg} / \mathrm{kg} \mathrm{BW/}$ day) failed to induce significant effects on body weight in 


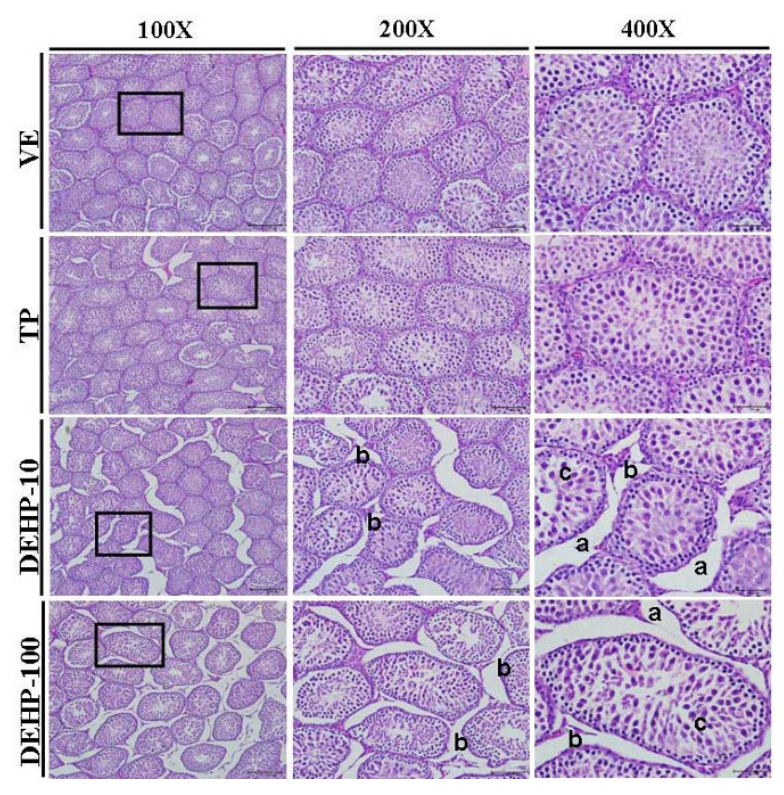

Figure 3

Effects of TP, DEHP ( $10,100 \mathrm{mg} / \mathrm{kg}$ BW/day) on histopathological changes in immature male rats exposed to EDs from PND 2 I to PND 35. Testis tissues were fixed in Bouin's solution and immersed in neutral formalin solution. The fixed tissues were embedded in paraffin, sectioned at $5 \mu \mathrm{m}$ and mounted on slides. These sections were stained with hematoxylin and eosin (i.e., HE) and histopathological changes were assessed under a light microscope. Dilatation of the tubular lumen (a: stained signals), degeneration of Leydig cells (b: stained signals), and disorder of germ cells (c: stained signals) were observed in the testes of immature male rats. Results are shown at a $100 \times$ magnification (i.e., bar $=200 \mu \mathrm{m}$ ), a $200 \times$ magnification (i.e., bar $=$ $100 \mu \mathrm{m}$ ) and a $400 \times$ magnification (i.e., bar $=50 \mu \mathrm{m}$ ).

a dose-dependent manner. However, high doses of DEHP and Flu significantly decreased the weights of reproductive organs, with the exception of the epididymis. Although treatment with high doses of DEHP failed to induce anti-androgenic effects on epididymis weight, these effects were observed after treatment with low doses of DEHP (i.e., $10 \mathrm{mg} / \mathrm{kg} \mathrm{BW/day).} \mathrm{These} \mathrm{results} \mathrm{provide}$ evidence of the anti-androgenic effects of DEHP in the epididymis. A previous study reported that treatment with DEHP (i.e., $500 \mathrm{mg} / \mathrm{kg} \mathrm{BW/day)} \mathrm{failed} \mathrm{to} \mathrm{induce} \mathrm{signifi-}$ cant effects on body weight [30]. However, other studies have shown significant decreases in body weight in response to Flu (i.e., 100 or $150 \mathrm{mg} / \mathrm{kg} \mathrm{BW/day)} \mathrm{[31],} \mathrm{sug-}$ gesting that these EDs differ markedly with regards to their detrimental affects on human and animals. Further studies are required to elucidate the molecular and biochemical mechanisms underlying the effects of anti-androgenic

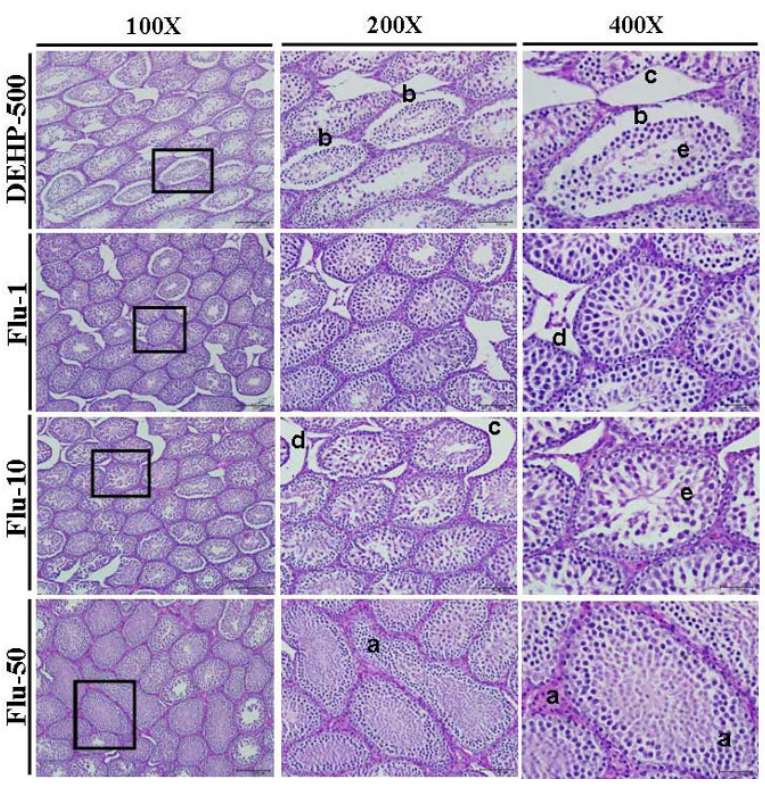

Figure 4

Effects of DEHP (500 mg/kg BW/day) and Flu on histopathological changes in immature male rats exposed to EDs from PND 2 I to PND 35. Testis tissues were fixed in Bouin's solution and immersed in neutral formalin solution. The fixed tissues were embedded in paraffin, sectioned at $5 \mu \mathrm{m}$ and mounted on slides. These sections were stained with hematoxylin and eosin (i.e., HE) and histopathological changes were assessed under a light microscope. Hyperplasia of Leydig cells, germ cell (a: stained signals), stratification of germ cells (b: stained signals), dilatation of the tubular lumen and stratification (c: stained signals), degeneration of Leydig cells (d: stained signals), and disorder of germ cells (e: stained signals) were observed in the testes of immature male rats. Results are shown at a 100 $\times$ magnification (i.e., bar $=200 \mu \mathrm{m}$ ), a $200 \times$ magnification (i.e., bar $=100 \mu \mathrm{m}$ ) and a $400 \times$ magnification (i.e., bar $=50$ $\mu \mathrm{m})$.

ED exposure in humans and animals, particularly during the critical stages of male reproductive development.

It has been suggested that alterations in endogenous androgen levels or dysregulation of gene expression patterns causes abnormalities in male reproductive tract (i.e., cyptochism, hypospadia, stunted testicular growth, epididymal abnormalities, and AGD [32-34]. In addition, the anti-androgenic and androgenic effects of EDs can be reflected by changes in the weights of the testes, prostate and seminal vesicle. A previous study of rat offspring indicated dose-dependent reductions in the ventral and dorsolateral prostate weights in response to DEHP [35]. Another study reported malformation of the male repro- 
Table 2: Up-regulated gene induced by TP, DEHP and Flu in the immature rat testes.

\begin{tabular}{|c|c|c|c|c|c|}
\hline \multirow[t]{2}{*}{ Transcript ID } & \multirow[t]{2}{*}{ Gene Symbol } & \multirow[t]{2}{*}{ Gene Name } & \multicolumn{3}{|c|}{ Fold change (compared with VE) } \\
\hline & & & vs TP & vS DEHP 100 & vs Flu IO \\
\hline \multicolumn{6}{|l|}{ TP UP } \\
\hline XM_345848 & Scrtl_predicted & scratch homolog I, zinc finger protein (Drosophila) & 5.88 & 1.84 & 1.46 \\
\hline$X M \_213394$ & Tmem93_predicted & transmembrane protein 93 (predicted) & 5.07 & 1.49 & 1.43 \\
\hline XM_21595I & Kcngl & potassium voltage-gated channel, subfamily $\mathrm{G}$, member I & 3.07 & 1.13 & 0.96 \\
\hline NM_001008295 & Fip III & FIPI like I (S. cerevisiae) & 2.44 & 1.00 & 1.08 \\
\hline NM_021669 & Ghrl & ghrelin precursor & 2.37 & 1.02 & 1.00 \\
\hline XM_221387 & Etv5_predicted & ets variant gene 5 (ets-related molecule) (predicted) & 2.14 & 1.01 & 1.13 \\
\hline XM_215635 & Apoalbp_predicted & apolipoprotein A-I binding protein (predicted) & 2.II & 1.31 & 1.22 \\
\hline NM_031802 & Gabbr2 & gamma-aminobutyric acid (GABA) B receptor 2 & 2.06 & 1.29 & 0.80 \\
\hline NM_I 33529 & Cabpl* & calcium binding protein I & 2.05 & 1.11 & 0.97 \\
\hline$X M \_216030$ & Vav2* & Vav2 oncogene (predicted) & 1.77 & 1.41 & 1.11 \\
\hline \multicolumn{6}{|l|}{ DEHP UP } \\
\hline XM_213289 & RGD/308066_predicted & similar to KIAAI960 protein (predicted) & 0.99 & 3.29 & 1.64 \\
\hline NM_0I26I6 & Omp & olfactory marker protein & 1.07 & 3.08 & 1.19 \\
\hline NM_021590 & Aipll & aryl hydrocarbon receptor-interacting protein-like I & 1.31 & 2.91 & 1.22 \\
\hline NM_031770 & Gnb5 & guanine nucleotide binding protein, beta 5 & 1.14 & 2.65 & 1.10 \\
\hline NM_001000980 & Olrl366 & olfactory receptor 1366 & 1.33 & 2.62 & 1.16 \\
\hline NM_022625 & Tpcl 808 & tropic 1808 & 1.11 & 2.43 & 1.36 \\
\hline NM_0010140I5 & $R b m 34$ & RNA binding motif protein 34 & 1.28 & 2.43 & 1.22 \\
\hline NM_19929I & Dox/2 & diamine oxidase-like protein 2 & 1.27 & 2.42 & 1.01 \\
\hline XM_220283 & Sox8_predicted & SRY-box containing gene 8 (predicted) & 1.10 & 2.33 & 1.18 \\
\hline NM_023992 & Kiss $/ r$ & KISSI receptor & 1.12 & 2.31 & 1.24 \\
\hline NM_00I000365 & Olr748_predicted & olfactory receptor 748 (predicted) & 1.21 & 2.30 & 1.26 \\
\hline NM_0I7035 & PlcdI* & phospholipase C, delta I & 1.20 & 2.20 & 1.24 \\
\hline XM_22I627 & BrwdI_predicted & $\begin{array}{l}\text { bromodomain and WD repeat domain containing I } \\
\text { (predicted) }\end{array}$ & 1.30 & 2.19 & 1.18 \\
\hline XM_22I52I & Hoxd4_predicted & homeo box D4 (predicted) & 0.67 & 2.17 & 0.93 \\
\hline XM_344627 & Calm4_predicted & calmodulin 4 (predicted) & 1.08 & 2.16 & 0.84 \\
\hline$X M \_216225$ & Ppp4r2_predicted & protein phosphatase 4 , regulatory subunit 2 (predicted) & 1.22 & 2.15 & 1.45 \\
\hline NM_I75587 & Taar7h & trace-amine-associated receptor $7 \mathrm{~h}$ & 1.14 & 2.14 & 1.11 \\
\hline NM_020106 & Olr4 I 4_predicted & olfactory receptor $4 \mid 4$ (predicted) & 1.35 & 2.13 & 0.94 \\
\hline NM_I45880 & LhxI* & LIM homeobox protein I & 1.04 & 1.72 & 1.20 \\
\hline \multicolumn{6}{|l|}{ Flu UP } \\
\hline XM_575355 & RGD/561053_predicted & similar to Claudin 12 (predicted) & 1.49 & 1.16 & 3.18 \\
\hline$X M \_218187$ & Cnot3_predicted & CCR4-NOT transcription complex, subunit 3 (predicted) & 1.21 & 1.10 & 2.48 \\
\hline NM_012992 & $\mathrm{NpmI}$ & nucleophosmin I & 1.31 & 1.13 & 2.25 \\
\hline NM_0I7265 & Hsd3bl* & $\begin{array}{l}\text { hydroxy-delta-5-steroid dehydrogenase, } 3 \text { beta- and steroid } \\
\text { delta-isomerase I }\end{array}$ & 0.87 & 0.97 & 2.18 \\
\hline$X M \_214673$ & Cog8_predicted & component of oligomeric golgi complex 8 (predicted) & 0.75 & 0.79 & 2.07 \\
\hline XM_225336 & Lrrcl6_predicted & leucine rich repeat containing 16 (predicted) & 1.00 & 1.31 & 2.06 \\
\hline XM_226843 & Rnasen & ribonuclease III, nuclear & 0.93 & 0.69 & 2.05 \\
\hline XM_234056 & RGD /564242_predicted & similar to KIAAI 218 protein (predicted) & 0.97 & 1.02 & 2.05 \\
\hline NM_013175 & Sgnel & secretory granule neuroendocrine protein I & 0.83 & 0.81 & 2.04 \\
\hline XM_221047 & Polg2_predicted & $\begin{array}{l}\text { polymerase (DNA directed), gamma 2, accessory subunit } \\
\text { (predicted) }\end{array}$ & 1.14 & 1.05 & 2.01 \\
\hline
\end{tabular}

The cDNA microarray analysis for detection of fold changes of gene expression in the testis of immature rats following treatments with TP, DEHP or Flu.

Altered gene up-regulation expression was estimated by the ratio of TP, DEHP $100 \mathrm{mg} / \mathrm{kg}$ BW/day and Flu $10 \mathrm{mg} / \mathrm{kg}$ BW/day treated vs. control as follows.

*, These altered genes were selected for verification by real- time PCR.

ductive tract following exposure to DEHP, manifesting as disgenesis of the epididymis, decreased sperm production, Leydig cell hyperplasia and adenomas [36]. A significant decrease in the weights of rat testes in response to DEHP (i.e., 250, 500, 1000 or $2000 \mathrm{mg} / \mathrm{kg}$ BW/day by gavage) has also been reported [37]. Another study dem- onstrated that the epididymal, prostate and seminal vesicle weights of immature male rats were strongly affected by the anti-androgenic effects of Flu at PND 20 [38]. Previous studies have proposed an androgen-dependent marker for the anti-androgenic and androgenic effects of EDs using AGD. A significant reduction in AGD is evoked 

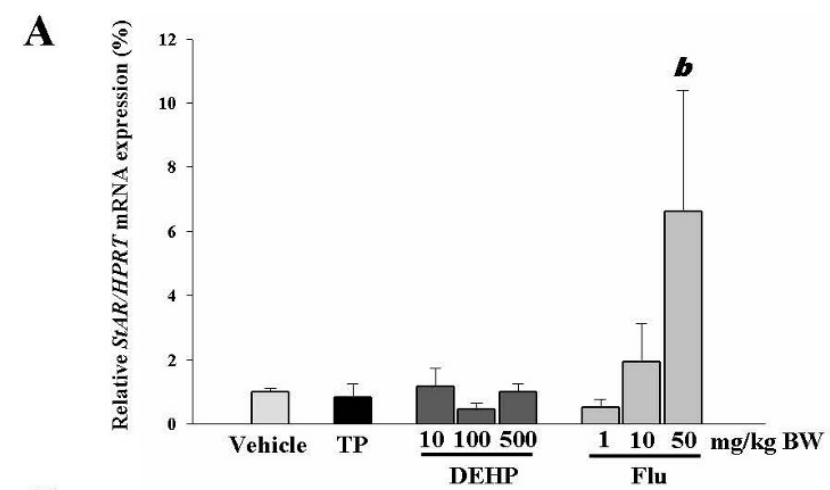

C

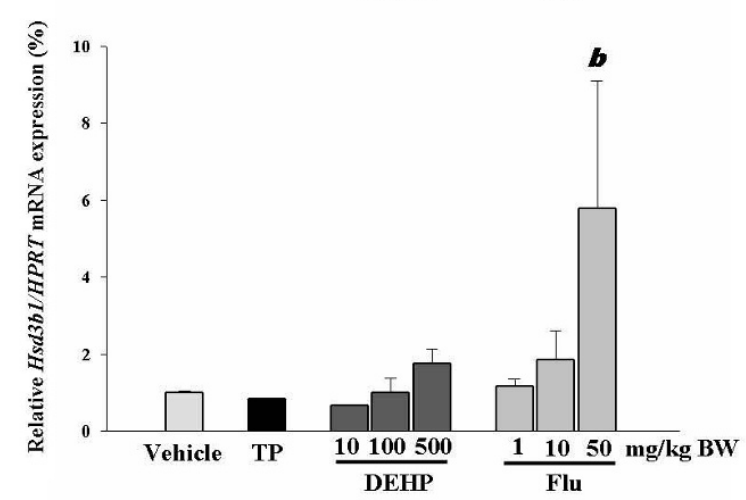

$\mathbf{E}$

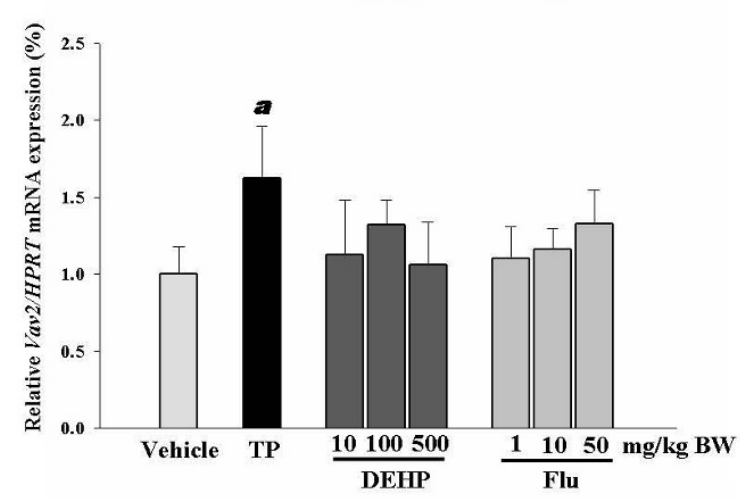

G

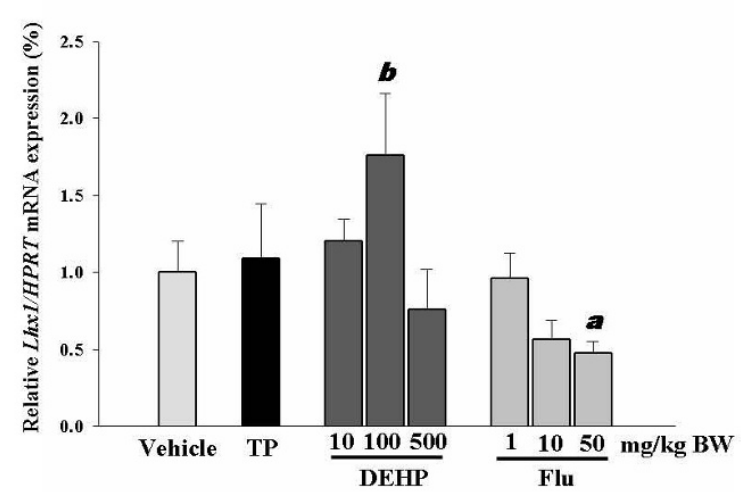

B

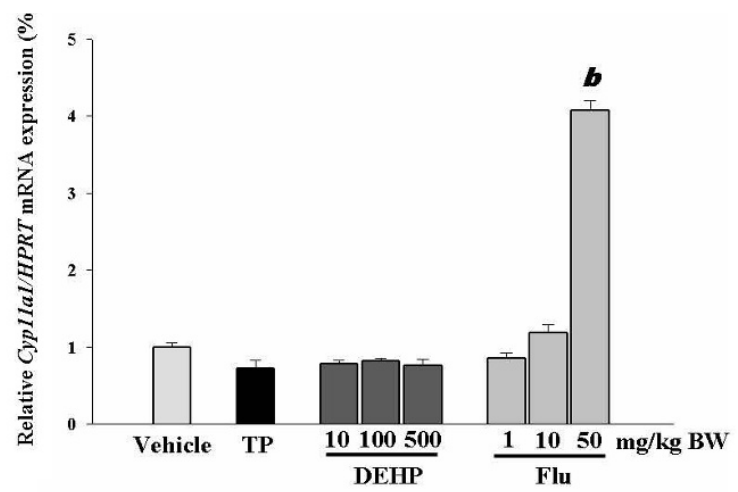

D

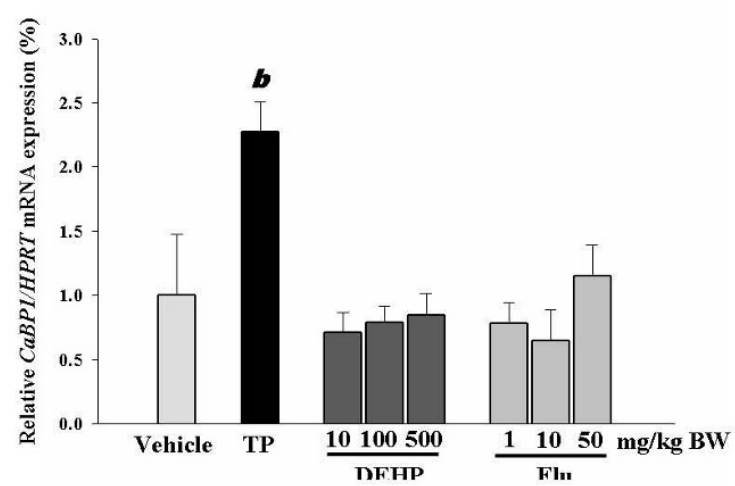

F

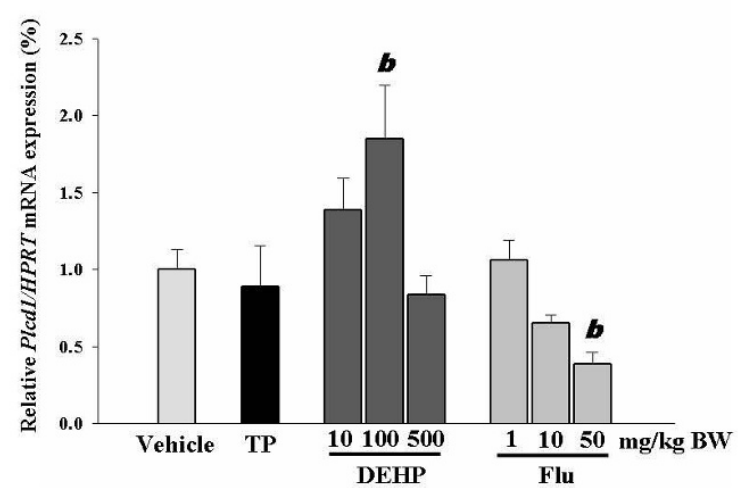

H

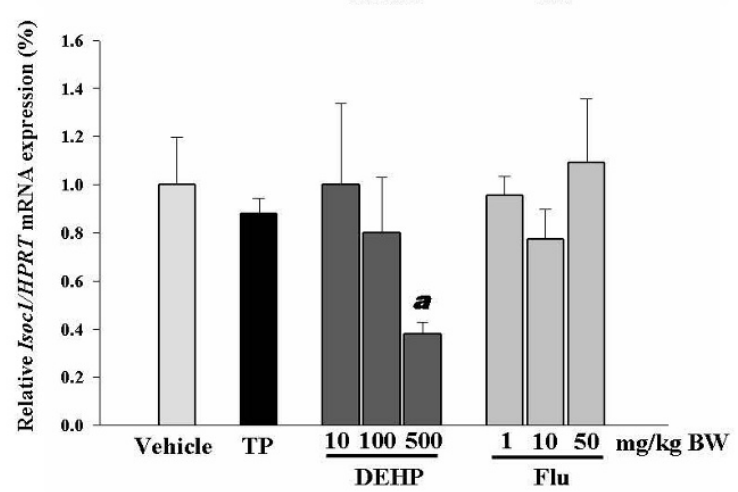

Figure 5

Altered gene expressions in steroidogenesis-related genes (i.e., StAR, Cyp I lal, HSD3bl), and a common gene set containing known TP, DEHP or Flu markers (i.e., CaBPI, Vav2, Plcdl, Lhxl, Isocl). Altered gene expressions were expressed relative to controls by real-time PCR as described in the Materials and Methods. Data are presented as means and SEMs (i.e., $n=4$ for each group). Asterisks denote significant differences, relative to a control (i.e., $p<0.05$ ). 
Table 3: Down-regulated gene induced by TP, DEHP and Flu in the immature rat testes.

\begin{tabular}{|c|c|c|c|c|c|}
\hline \multirow[t]{2}{*}{ Transcript ID } & \multirow[t]{2}{*}{ Gene Symbol } & \multirow[t]{2}{*}{ Gene Name } & \multicolumn{3}{|c|}{ Fold change (compared with VE) } \\
\hline & & & vs TP & vs DEHP 100 & vs Flu 10 \\
\hline \multicolumn{6}{|l|}{ TP DOWN } \\
\hline NM_00I0I 2225 & Mgat4a & $\begin{array}{l}\text { Mannoside acetylglucosaminyltransferase } \\
4 \text {, isoenzyme } A\end{array}$ & 0.30 & 0.69 & 0.74 \\
\hline XM_214360 & Ubxd6_predicted & UBX domain containing 6 (predicted) & 0.35 & 0.82 & 0.63 \\
\hline XM_342534 & Nat5_predicted & $\begin{array}{l}\mathrm{N} \text {-acetyltransferase } 5 \text { (ARDI homolog, S. cerevisiae) } \\
\text { (predicted) }\end{array}$ & 0.39 & 0.77 & 1.03 \\
\hline NM_053356 & Colla2 & procollagen, type I, alpha 2 & 0.42 & 0.81 & 0.79 \\
\hline XM_345107 & RGD /559810_predicted & similar to hypothetical protein (predicted) & 0.42 & 0.83 & 0.77 \\
\hline NM_I33317 & Tobl & transducer of ErbB-2.I & 0.43 & 0.82 & 1.04 \\
\hline XM_34I903 & Nrip3_predicted & nuclear receptor interacting protein 3 (predicted) & 0.44 & 1.90 & 1.87 \\
\hline XM_229139 & RGD/566225_predicted & similar to RIKEN cDNA I 70000 IF22 (predicted) & 0.44 & 1.00 & 0.82 \\
\hline NM_001013185 & Cabcl & chaperone, $\mathrm{ABCl}$ activity of bcl complex like (S. pombe) & 0.45 & 1.08 & 0.73 \\
\hline XM_235640 & Tmem I 6f_predicted & transmembrane protein $16 \mathrm{~F}$ (predicted) & 0.46 & 0.87 & 0.68 \\
\hline NM_001010966 & Pigv & phosphatidylinositol glycan, class $\mathrm{V}$ & 0.49 & 2.21 & 1.73 \\
\hline NM_I33318 & Khdrbs2 & $\begin{array}{l}\mathrm{KH} \text { domain containing, RNA binding, signal transduction } \\
\text { associated } 2\end{array}$ & 0.49 & 0.82 & 0.85 \\
\hline \multicolumn{6}{|l|}{ DEHP DOWN } \\
\hline XM_218447 & RGDI56/I2I_predicted & $\begin{array}{l}\text { similar to pleckstrin homology-like domain, family B, member } \\
3 \text { (predicted) }\end{array}$ & 1.26 & 0.12 & 0.99 \\
\hline NM_199092 & Orc4l & origin recognition complex, subunit 4-like (S. cerevisiae) & 0.70 & 0.40 & 0.72 \\
\hline NM_03I753 & Alcam & activated leukocyte cell adhesion molecule & 0.75 & 0.46 & 0.80 \\
\hline NM_001014242 & $\mid$ socl* & isochorismatase domain containing $I$ & 0.85 & 0.46 & 0.90 \\
\hline XM_215497 & RadI_predicted & RADI homolog (S. pombe) (predicted) & 0.97 & 0.46 & 0.86 \\
\hline XM_575065 & RGDI559623_predicted & similar to RIKEN cDNA 5230400J09 (predicted) & 0.93 & 0.48 & 0.69 \\
\hline NM_139189 & LmbrdI & LMBRI domain containing I & 0.76 & 0.48 & 0.74 \\
\hline XM_236578 & RGDI562949_predicted & similar to mKIAA0259 protein (predicted) & 0.91 & 0.49 & 1.26 \\
\hline XM_215487 & Mrps30_predicted & mitochondrial ribosomal protein S30 (predicted) & 0.90 & 0.49 & 0.76 \\
\hline \multicolumn{6}{|l|}{ Flu DOWN } \\
\hline NM_00I000234 & Olr297_predicted & olfactory receptor 297 (predicted) & 1.02 & 1.54 & 0.25 \\
\hline XM_236348 & Cilp_predicted & $\begin{array}{l}\text { cartilage intermediate layer protein, nucleotide } \\
\text { pyrophosphohydrolase (predicted) }\end{array}$ & 0.65 & 0.89 & 0.40 \\
\hline XM_228462 & RGDI56544I_predicted & similar to KIAAI 687 protein (predicted) & 0.90 & 1.02 & 0.43 \\
\hline XM_219296 & Rbbp6 & retinoblastoma binding protein 6 & 0.65 & 0.82 & 0.45 \\
\hline NM_021653 & Diol & deiodinase, iodothyronine, type I & 0.97 & 0.97 & 0.46 \\
\hline
\end{tabular}

Altered gene down-regulation expression was estimated by the ratio of TP, DEHP $100 \mathrm{mg} / \mathrm{kg} \mathrm{BW} /$ day and Flu $10 \mathrm{mg} / \mathrm{kg}$ BW/day treated vs. control as follows.

*, These altered genes were selected for verification by real- time PCR.

by DEHP exposure during lactation [39] and by prenatal exposure to Flu [40]. Moreover, changes in AGD during early postnatal periods correlate with alterations in androgen-dependent development in adults [41]. In the present study, AGD values decreased significantly in response to high doses of DEHP or Flu; however, no alterations were observed after treatment with their medium and low doses. Although there is a correlation between EDs and reproductive, developmental and behavioral changes at high doses in experimental animals, further studies are required to determine if low doses may also contribute to reproductive disorders in humans and wildlife [39].

A recent study has indicated the property of phthalates associated with endocrine disruption and these compounds are believed to act as endocrine disruptors [42]. Exposure to phthalates reduces testosterone synthesis dur- ing this critical stage of development [7]. Phthalates exert their effects on steroidogenesis in Leydig cells via modulation of testosterone-biosynthetic enzyme activity and serum LH levels [43]. In contrast, different responses to Flu may result from local concentrations of androgenic and anti-androgenic compounds. Exposure to Flu may block the physiological action of testosterone at AR sites [44] and induce changes in circulating LH levels, due to disturbances in the negative feedback loop between the pituitary and the testis [40]. Although DEHP and Flu share an anti-androgenic activity, the mechanisms by which these EDs exert their effects on human body are distinct. It has indicated in many previous reports that AR plays an important role in Flu-mediated response, while phthalates, including DEHP, do not interact with $\mathrm{AR}$ at the physiological concentration [45]. Additionally, DEHP is thought to activate PPAR, leading a down-regulation of 
Table 4: Functional Categorization of Genes Significantly Altered via microarray analysis in immature male testes following TP, DEHP and Flu exposure

\begin{tabular}{|c|c|c|}
\hline Functional category & Transcript ID & Gene Symbol \\
\hline \multirow[t]{2}{*}{ Steroid hormone biosynthetic process } & NM_031558 & Star \\
\hline & NM_0I7286 & Cypl Ial \\
\hline \multirow[t]{8}{*}{ Regulation of Transcription } & XM_22I387 & Etv5_predicted \\
\hline & XM_220283 & Sox8_predicted \\
\hline & XM_22I52I & Hoxd4_predicted \\
\hline & NM_I45880 & LhxI \\
\hline & XM_218187 & Cnot3_predicted \\
\hline & XM_229139 & RGD/566225_predicted \\
\hline & XM_221627 & Brwdl_predicted \\
\hline & NM_133317 & Tobl \\
\hline \multirow[t]{11}{*}{ Signal Transduction } & NM_031802 & Gabbr2 \\
\hline & XM_216030 & Vav2_predicted \\
\hline & NM_012616 & Omp \\
\hline & NM_031770 & Gnb5 \\
\hline & NM_001000980 & Olr 1366 \\
\hline & NM_023992 & Kiss /r \\
\hline & NM_I 175587 & Taar7h \\
\hline & NM_020106 & Olr4 I4_predicted \\
\hline & NM_0I 2992 & Npml \\
\hline & NM_031753 & Alcam \\
\hline & XM_344627 & Calm4_predicted \\
\hline \multirow[t]{5}{*}{ Metabolic process } & NM_021590 & Aipll \\
\hline & NM_00I0I2225 & Mgat4a \\
\hline & XM_342534 & Nat5_predicted \\
\hline & NM_001014242 & $\mid \mathrm{socl}$ \\
\hline & XM_236348 & Cilp_predicted \\
\hline \multirow[t]{2}{*}{ Catabolic process } & NM_022625 & $T p c / 808$ \\
\hline & NM_0I7035 & PlcdI \\
\hline \multirow[t]{3}{*}{ Biosynthetic process } & NM_0I7265 & $H s d 3 b l$ \\
\hline & NM_00I010966 & Pigv \\
\hline & NM_021653 & Diol \\
\hline \multirow[t]{8}{*}{ Integral to membrane } & XM_213394 & Tmem93_predicted \\
\hline & NM_00I000365 & Olr748_predicted \\
\hline & XM_575355 & RGD I561053_predicted \\
\hline & XM_214673 & Cog8_predicted \\
\hline & XM_214360 & Ubxd6_predicted \\
\hline & NM_00I000234 & Olr297_predicted \\
\hline & NM_139189 & Lmbrd I \\
\hline & XM_235640 & Tmem I6f_predicted \\
\hline \multirow[t]{2}{*}{ Mitochondrion } & NM_001013185 & Cabcl \\
\hline & XM_2I5487 & Mrps30_predicted \\
\hline \multirow[t]{8}{*}{ Protein binding } & XM_2I5635 & Apoalbp_predicted \\
\hline & NM_133529 & Cabpl \\
\hline & NM_0I3175 & Sgnel \\
\hline & XM_221047 & Polg2_predicted \\
\hline & NM_053356 & Colla2 \\
\hline & NM_133318 & Khdrbs2 \\
\hline & XM_228462 & RGD I56544I_predicted \\
\hline & XM_219296 & Rbbp6 \\
\hline
\end{tabular}


Table 4: Functional Categorization of Genes Significantly Altered via microarray analysis in immature male testes following TP, DEHP and Flu exposure (Continued)

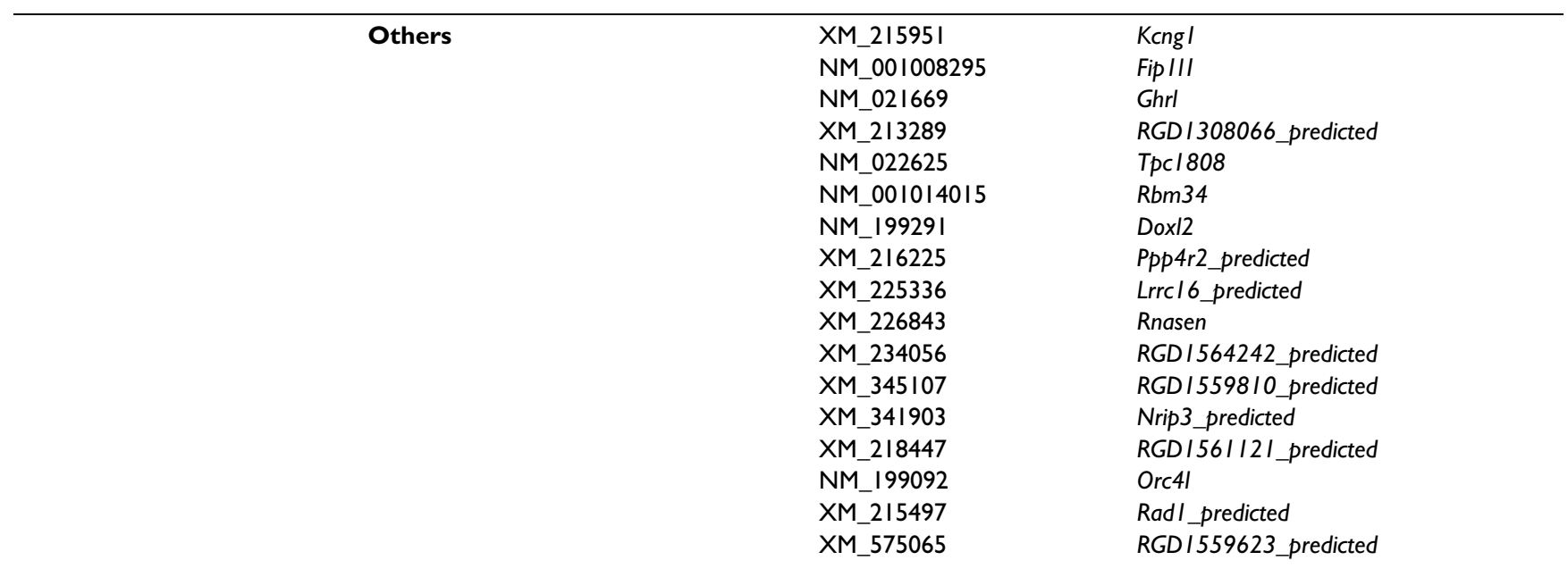

SR-B1 and PBR or effects on SF-1 to consequently regulate steroidogenesis-related genes [16]. To further understand the effects of DEHP and Flu during the critical stages of male reproductive development, we measured the serum concentrations of testosterone and LH. However, exposure to all doses of Flu and DEHP failed to induce a significant effect in the serum LH levels, while a significant decreased level in the serum concentrations of testosterone was observed in response to all doses of DEHP. We did not expect to observe Flu-induced effect on serum concentrations of testosterone and $\mathrm{LH}$, however, the response of Flu on their serum concentrations may be explained by the lack of a negative feedback mechanism. Further experiments with larger sample sizes are required to verify these findings. It has been indicated that exposure to a high dose of DEHP caused a decrease in testosterone production and consequently reduced AGD value [46]. In this study, serum testosterone concentration and AGD value were reduced in response to a high dose of DEHP, suggesting that an alteration in testosterone synthesis may result from phthalate-induced dysfunctional interaction between Leydig and Sertoli cells [47]. Thus, the pathological changes induced by anti-androgenic effects in the testis during male reproductive tract development may alter serum testosterone levels.

Testes are androgen-responsive tissues, and alterations in the morphology and histology of testes can reflect the anti-androgenicity effects of chemicals. In addition, an evaluation of histological and biological effects is very important to understand the potential risk impacts for spermatogenesis from endocrine disrupting chemicals [48]. In this study, histopathological changes in the testes of immature male rats exposed to DEHP and Flu were examined, and abnormalities in the cell morphology and histology of the testes were observed (i.e., abnormal testicular development or dysgenesis, Leydig cell hyperplasia, morphologically distorted tubules, differentiated Sertoli cells and abnormal germ cells), particularly in response to high doses of DEHP and Flu. A previous study indicated that in utero exposure to DEHP $(1,000 \mathrm{mg} / \mathrm{kg} \mathrm{BW})$ caused the dilatation and atrophy of seminiferous tubules in rats. In addition, exposure to DEHP (500 mg/kg BW) may result in the abnormalities of the cell morphology in which multinucleated germ cells were observed in seminiferous cords [49]. Another study has indicated the agerelated difference in the toxic effect(s) of this ED in the testis of rats [50]. A testicular atrophy and/or a decline in zinc concentration were observed when exposure of immature rats to DEHP [51], demonstrating the DEHP- and Fluinduced effects on male reproductive development, particularly with regards to spermatogenesis.

A previous study has investigated the alteration in the gene expression following DEHP treatment in which exposure to this compound caused a dysregulation in the expression of many genes, including apoptosis-, cell proliferation-, metabolism-, cell adhesion- and immune response- related genes [52]. In this study, the gene expression in immature rat testes was also assessed via cDNA microarray assays. A total of 37,317 genes were dysregulated in response to DEHP (i.e., $100 \mathrm{mg}$ ) and Flu (i.e., $10 \mathrm{mg}$ ) treatment, when compared with a control. Among these genes, 1,272 were overexpressed by more than two fold, and 1,969 genes were downregulated (Table 2 and $3)$. Some of these genes were chosen for use as marker genes. We previously demonstrated that maternal exposure to DEHP and Flu modulates the expression of fetal StAR, Cyp11a1 and Hsd3b1 genes, wherein DEHP treatment downregulated transcription [53]. However, no significant effects were observed in the current study. Interestingly, treatment with high doses of Flu significantly increased the expression of these genes (i.e., by 4 to 6-fold). Several genes shown in Table 2 and 3 [i.e., cal- 
cium binding protein 1(CaBP1); vav2 oncogene- predicted (Vav2-predicted); phospholipase C delta 1 (Plcd1); lim homeobox protein 1 (Lhx1) and isochorismatase domain containing 1 (Isoc1)] were previously identified because of their direct or indirect involvement in physiological processes (e.g., lipid or steroid metabolism, sex determination, calcium transduction or cell proliferation). However, the biological interactions of these proteins in response to EDs (i.e., particularly DEHP and Flu) remains unknown. In current study, we also found that some genes were strongly up-regulated by TP treatment, whereas no differences at transcriptional levels were observed in the testes of rats exposed to DEHP and/or Flu. Furthermore, expression of other genes, including nuclear receptor interacting protein 3 (predicted) and phosphatidylinositol glycan, class $\mathrm{V}$, were decreased markedly in TP treated group, while an enhancement in expression of these genes was observed following DEHP or Flu treatment. A distinct response to TP and DEHP/Flu may reflect hormone properties of tested chemicals. Additionally, a different pattern of gene expression also was found between DEHP and Flu treatment. These distinct responses to DEHP and Flu may be explained by the differential mechanism of actions of the two anti-androgenic EDs. The discrepancy was observed in the microarray results compared to the previous ones, which appears to be derived from different microarray system employed and different experimental environments among the studies.

It has been reported that calcium binding protein-1 (i.e., encoded by $C a B P 1)$ functions as a calmodulin-like protein that modulates $\mathrm{Ca} 2+$ channel activities [54]. An interaction between $\mathrm{Ca} 2+$ channels and $\mathrm{CaBP} 1$ may regulate the Ca2+-dependent forms of synaptic plasticity by inhibiting Ca2+ influx into neurons [55]. In this study, the expression of $C a B P 1$ was significantly up-regulated by TP exposure. Our data revealed that exposure to TP activated the predicted Vav2 oncogene. The Vav2 gene is involved in many biological processes, including the B- and T-cell receptor signaling pathways, leukocyte transendothelial migration, natural killer cell-mediated cytotoxicity and regulation of the actin cytoskeleton. Some previous studies have demonstrated an appearance of CaBP1 and Vav2 oncogene genes during spermatogenesis, suggesting their potential roles in the critical window stage of male reproductive system development [56,57]. Phospholipase C delta 1 ( $P l c d 1)$, a ubiquitous enzyme, helps regulate a variety of cellular processes. The Plcd1 gene has been detected in the plasma membrane, the cytoplasm [58], and liver mitochondria [59], and the involvement of Plcd in cardiac function has also been reported [60]. In addition, the activity of Plcd1 is affected by cytoplasmic concentrations of $\mathrm{Ca} 2+$ [61]. A previous study also demonstrated that FSH-induced $\mathrm{Ca}(2+)$ influx is mediated by the Plcd1 sign- aling pathway in rat Sertoli cells [62]. Moreover, a testosterone-induced increase in intracellular Ca2+ occurs via activation of a plasma membrane receptor associated with the phospholipase $\mathrm{C}$ signaling pathway [63]. Our results revealed a significant increase in the expression of its pathway. In addition, we found that the expression of LIM homeobox gene 1 ( $L h x 1$ ) was significantly modulated by DEHP, suggesting that this gene is a potential indicator for the effects of DEHP on androgen-responsive tissues. As a member of the large homeobox gene family, Lhx1 plays an important role in the stabilization of the intermediate mesoderm and in the formation of urogenital ridges [64]. This gene is expressed in the comma- and S-shaped bodies of the metanephric mesenchyme, as well as the developing Müllerian duct [65]. In the male reproductive system, Lhx1 plays an important role in early gonad development, sex-reversal and gonadal cell proliferation. Several studies have reported the involvement of Isoc1 in progressive chronic renal failure in rats [66]. Sexual hormones (e.g., estradiol, testosterone, prolactin and FSH) concentrations are commonly affected by chronic renal failure and the dysfunction of sex steroids may contribute to the emergence of renal osteodystrophy [67]. Our results showed a 6 -fold downregulation in Isco1 gene expression after exposure to DEHP, representing an anti-androgen-like ED exposure. These results demonstrate the effects of EDs on sexual hormone abnormalities, and are likely to induce similar changes in the reproductive development of male humans and rats. Overall, our data indicated that the these changes may reflect an impact of chemical exposure on transcriptional level of gene expression and associated with histology changes of Leydig cells, Sertoli cells and/or germ cells, however the role(s) of these altered genes to explain a change in altered phenotype or morphology has unknown. It is expected for us to investigate the molecular events of these maker genes in the histopathological testis changes when EDs exposure during the critical male reproductive development stage in a further study.

Taken together, our findings indicate that exposure to DEHP and Flu results in an alteration in gene expression in the testes of immature male rats. In addition, these chemicals exert distinct anti-androgenic effects on the male reproductive system. Our findings provide new insight into the molecular mechanisms underlying the detrimental impacts of anti-androgenic-EDs in androgenresponsive organs, in particular, in developing male reproductive tracts.

\section{Competing interests}

The authors declare that they have no competing interests.

\section{Authors' contributions}

TTPV and EMJ carried out the overall experiments to complete this study and drafted the manuscript. VHD and 
YMY performed experiments, in part, and drafted the manuscript. KCC performed real-time PCR and drafted and completed the manuscript. FHY participated in its design and coordination and performed the statistical analysis. EBJ conceived of the study, and participated in its design and coordination and helped to draft the manuscript. All authors read and approved the final manuscript.

\section{Acknowledgements}

This work was supported by a grant (07/42KFDA593) from the Korean Food \& Drug Administration in 2007.

\section{References}

I. Forman D, Moller H: Testicular cancer. Cancer Surv 1994, I920:323-341.

2. Andersen AG, Jensen TK, Carlsen E, Jorgensen N, Andersson AM, Krarup T, Keiding N, Skakkebaek NE: High frequency of sub-optimal semen quality in an unselected population of young men. Hum Reprod 2000, I 5(2):366-372.

3. Paulozzi LJ, Erickson JD, Jackson RJ: Hypospadias trends in two US surveillance systems. Pediatrics 1997, I00(5):83 I-834.

4. Fisher JS: Environmental anti-androgens and male reproductive health: focus on phthalates and testicular dysgenesis syndrome. Reproduction 2004, I 27(3):305-3I5.

5. Mylchreest E, Sar M, Cattley RC, Foster PM: Disruption of androgen-regulated male reproductive development by di(nbutyl) phthalate during late gestation in rats is different from flutamide. Toxicol Appl Pharmacol 1999, I 56(2):81-95.

6. Sharpe RM: The 'oestrogen hypothesis'- where do we stand now? Int J Androl 2003, 26(I):2-I5.

7. Parks LG, Ostby JS, Lambright CR, Abbott BD, Klinefelter GR, Barlow NJ, Gray LE: The plasticizer diethylhexyl phthalate induces malformations by decreasing fetal testosterone synthesis during sexual differentiation in the male rat. Toxicol Sci 2000 , 58(2):339-349.

8. Gray LE Jr, Ostby J, Furr J, Price M, Veeramachaneni DN, Parks L: Perinatal exposure to the phthalates DEHP, BBP, and DINP, but not DEP, DMP, or DOTP, alters sexual differentiation of the male rat. Toxicol Sci 2000, 58(2):350-365.

9. Skakkebaek NE, Holm M, Hoei-Hansen C, Jorgensen N, Rajpert-De Meyts E: Association between testicular dysgenesis syndrome (TDS) and testicular neoplasia: evidence from 20 adult patients with signs of maldevelopment of the testis. Apmis 2003, I I I ( I): I-9.

10. Kavlock R, Boekelheide K, Chapin R, Cunningham M, Faustman E, Foster P, Golub M, Henderson R, Hinberg I, Little R, Seed J, Shea K, Tabacova S, Tyl R, Williams P, Zacharewski T: NTP Center for the Evaluation of Risks to Human Reproduction: phthalates expert panel report on the reproductive and developmental toxicity of di-n-octyl phthalate. Reprod Toxicol 2002, I 6(5):721-734.

II. Andrade AJ, Grande SW, Talsness CE, Gericke C, Grote K, Golombiewski A, Sterner-Kock A, Chahoud I: A dose response study following in utero and lactational exposure to di-(2-ethylhexyl) phthalate (DEHP): reproductive effects on adult male offspring rats. Toxicology 2006, 228(I):85-97.

12. Kolpin DW, Furlong ET, Meyer MT, Thurman EM, Zaugg SD, Barber LB, Buxton HT: Pharmaceuticals, hormones, and other organic wastewater contaminants in U.S. streams, 19992000: a national reconnaissance. Environ Sci Technol 2002, 36(6): |202-|2||.

13. Silva RC, Meurer EC, Eberlin MN, Augusto F: Determination of phthalates in water using fiber introduction mass spectrometry. Analyst 2005, I30(2): I88-192.

14. Mortensen GK, Main KM, Andersson AM, Leffers H, Skakkebaek NE: Determination of phthalate monoesters in human milk, consumer milk, and infant formula by tandem mass spectrometry (LC-MS-MS). Anal Bioanal Chem 2005, 382(4): I084-I092.

15. Green AR, Styles JA, Parrott EL, Gray D, Edwards RE, Smith AG, Gant TW, Greaves P, Al-Azzawi F, White IN: Neonatal tamoxifen treatment of mice leads to adenomyosis but not uterine cancer. Exp Toxicol Pathol 2005, 56(4-5):255-263.

16. Borch J, Metzdorff SB, Vinggaard AM, Brokken L, Dalgaard M: Mechanisms underlying the anti-androgenic effects of diethylhexyl phthalate in fetal rat testis. Toxicology 2006, 223(1-2): |44-I55.

17. Supornsilchai V, Soder O, Svechnikov K: Stimulation of the pituitary-adrenal axis and of adrenocortical steroidogenesis ex vivo by administration of di-2-ethylhexyl phthalate to prepubertal male rats. J Endocrinol 2007, I 92(I):33-39.

18. Svechnikova I, Svechnikov K, Soder O: The influence of di-(2ethylhexyl) phthalate on steroidogenesis by the ovarian granulosa cells of immature female rats. J Endocrinol 2007 , I94(3):603-609.

19. Sharpe RM, McKinnell C, Kivlin C, Fisher JS: Proliferation and functional maturation of Sertoli cells, and their relevance to disorders of testis function in adulthood. Reproduction 2003, I 25(6):769-784.

20. Jones HB, Garside DA, Liu R, Roberts JC: The influence of phthalate esters on Leydig cell structure and function in vitro and in vivo. Exp Mol Pathol 1993, 58(3): 179-193.

21. Barlow NJ, Phillips SL, Wallace DG, Sar M, Gaido KW, Foster PM: Quantitative changes in gene expression in fetal rat testes following exposure to di(n-butyl) phthalate. Toxicol Sci 2003 , 73(2):43I-44I.

22. Lahousse SA, Wallace DG, Liu D, Gaido KW, Johnson KJ: Testicular gene expression profiling following prepubertal rat mono-(2ethylhexyl) phthalate exposure suggests a common initial genetic response at fetal and prepubertal ages. Toxicol Sci 2006, 93(2):369-38I.

23. Murphy WM, Soloway MS, Barrows GH: Pathologic changes associated with androgen deprivation therapy for prostate cancer. Cancer 1991, 68(4):82 I-828.

24. Kassim NM, McDonald SW, Reid O, Bennett NK, Gilmore DP, Payne $A P$ : The effects of pre- and postnatal exposure to the nonsteroidal antiandrogen flutamide on testis descent and morphology in the Albino Swiss rat. J Anat 1997, I 90(Pt 4):577-588.

25. Mathur PP, Chattopadhyay S: Involvement of lysosomal enzymes in flutamide-induced stimulation of rat testis. Andrologia 1982, | 4(2): | 71 - | 76.

26. Ohsako S, Kubota K, Kurosawa S, Takeda K, Qing W, Ishimura R, Tohyama C: Alterations of gene expression in adult male rat testis and pituitary shortly after subacute administration of the antiandrogen flutamide. J Reprod Dev 2003, 49(4):275-290.

27. Yang YH, Dudoit S, Luu P, Lin DM, Peng V, Ngai J, Speed TP: Normalization for cDNA microarray data: a robust composite method addressing single and multiple slide systematic variation. Nucleic Acids Res 2002, 30(4): I 5.

28. Hong EJ, Park SH, Choi KC, Leung PC, Jeung EB: Identification of estrogen-regulated genes by microarray analysis of the uterus of immature rats exposed to endocrine disrupting chemicals. Reprod Biol Endocrinol 2006, 4:49.

29. Culty M, Thuillier R, Li W, Wang Y, Martinez-Arguelles DB, Benjamin CG, Triantafilou KM, Zirkin BR, Papadopoulos V: In Utero Exposure to Di-(2-ethylhexyl) Phthalate Exerts Both Short-Term and Long-Lasting Suppressive Effects on Testosterone Production in the Rat. Biol Reprod 2008, 78(6): $1018-1028$.

30. Howdeshell KL, Furr J, Lambright CR, Rider CV, Wilson VS, Gray LE Jr: Cumulative effects of dibutyl phthalate and diethylhexyl phthalate on male rat reproductive tract development: altered fetal steroid hormones and genes. Toxicol Sci 2007, 99(I): 190-202.

31. Friry-Santini C, Rouquie D, Kennel P, Tinwell H, Benahmed M, Bars $\mathrm{R}$ : Correlation between protein accumulation profiles and conventional toxicological findings using a model antiandrogenic compound, flutamide. Toxicol Sci 2007, 97(I):8I-93.

32. McKinnell C, Atanassova N, Williams K, Fisher JS, Walker M, Turner KJ, Saunders TK, Sharpe RM: Suppression of androgen action and the induction of gross abnormalities of the reproductive tract in male rats treated neonatally with diethylstilbestrol. J Androl 200I, 22(2):323-338.

33. Rivas A, Fisher JS, McKinnell C, Atanassova N, Sharpe RM: Induction of reproductive tract developmental abnormalities in the male rat by lowering androgen production or action in combination with a low dose of diethylstilbestrol: evidence for importance of the androgen-estrogen balance. Endocrinology 2002, I 43( I 2):4797-4808. 
34. Barlow NJ, Foster PM: Pathogenesis of male reproductive tract lesions from gestation through adulthood following in utero exposure to Di(n-butyl) phthalate. Toxicol Pathol 2003, 3 I (4):397-4I0.

35. Moore RW, Rudy TA, Lin TM, Ko K, Peterson RE: Abnormalities of sexual development in male rats with in utero and lactational exposure to the antiandrogenic plasticizer Di(2-ethylhexyl) phthalate. Environ Health Perspect 200I, I 09(3):229-237.

36. Kobayashi K, Miyagawa M, Wang RS, Suda M, Sekiguchi S, Honma T: Effects of in utero and lactational exposure to di(2-ethylhexyl)phthalate on somatic and physical development in rat offspring. Ind Health 2006, 44(4):652-660.

37. Srivastava S, Srivastava SP: Effect of di(2-ethylhexyl)phthalate on I 7 beta-hydroxysteroid dehydrogenase activity in testis of rat. Toxicol Lett |99|, 57(2):235-239.

38. Tinwell H, Friry-Santini C, Rouquie D, Belluco S, Elies L, Pallen C, Bars $\mathrm{R}$ : Evaluation of the antiandrogenic effects of flutamide, DDE, and linuron in the weanling rat assay using organ weight, histopathological, and proteomic approaches. Toxicol Sci 2007, I 00(I):54-65.

39. Andrade AJ, Grande SW, Talsness CE, Grote K, Golombiewski A, Sterner-Kock A, Chahoud I: A dose-response study following in utero and lactational exposure to di-(2-ethylhexyl) phthalate (DEHP): effects on androgenic status, developmental landmarks and testicular histology in male offspring rats. Toxicology 2006, 225(I):64-74.

40. Miyata K, Yabushita S, Sukata T, Sano M, Yoshino H, Nakanishi T, Okuno Y, Matsuo M: Effects of perinatal exposure to flutamide on sex hormones and androgen-dependent organs in $\mathrm{FI}$ male rats. J Toxicol Sci 2002, 27(I):19-33.

4I. Mylchreest E, Sar M, Wallace DG, Foster PM: Fetal testosterone insufficiency and abnormal proliferation of Leydig cells and gonocytes in rats exposed to di(n-butyl) phthalate. Reprod Toxicol 2002, 16(I): 19-28.

42. Parveen M, Inoue A, Ise R, Tanji M, Kiyama R: Evaluation of estrogenic activity of phthalate esters by gene expression profiling using a focused microarray (EstrArray). Environ Toxicol Chem 2008, 27(6): |4|6-|425.

43. Akingbemi BT, Youker RT, Sottas CM, Ge R, Katz E, Klinefelter GR, Zirkin BR, Hardy MP: Modulation of rat Leydig cell steroidogenic function by di(2-ethylhexyl)phthalate. Biol Reprod 200I, 65(4): $1252-1259$.

44. Gray LE Jr, Kelce WR, Wiese T, Tyl R, Gaido K, Cook J, Klinefelter G, Desaulniers D, Wilson E, Zacharewski T, Waller C, Foster P, Laskey 」, Reel J. Giesy J, Laws S, McLachlan J, Breslin W, Cooper R, Di Giulio R, Johnson R, Purdy R, Mihaich E, Safe S, Colborn T: Endocrine Screening Methods Workshop report: detection of estrogenic and androgenic hormonal and antihormonal activity for chemicals that act via receptor or steroidogenic enzyme mechanisms. Reprod Toxicol 1997, I I (5):719-750.

45. Gray LE Jr, Wilson VS, Stoker T, Lambright C, Furr J, Noriega N, Howdeshell K, Ankley GT, Guillette L: Adverse effects of environmental antiandrogens and androgens on reproductive development in mammals. Int J Androl 2006, 29(I):96-104. discussion I05-108

46. Ge RS, Chen GR, Tanrikut C, Hardy MP: Phthalate ester toxicity in Leydig cells: developmental timing and dosage considerations. Reprod Toxicol 2007, 23(3):366-373.

47. Mahood IK, McKinnell C, Walker M, Hallmark N, Scott H, Fisher JS, Rivas A, Hartung S, Ivell R, Mason Jl, et al.: Cellular origins of testicular dysgenesis in rats exposed in utero to di(n-butyl) phthalate. Int J Androl 2006, 29(I): |48-154. discussion I8I-|45

48. Anahara R, Toyama $Y$, Mori C: Review of the histological effects of the anti-androgen, flutamide, on mouse testis. Reprod Toxicol 2008, 25(2): I39-143.

49. Shirota M, Saito Y, Imai K, Horiuchi S, Yoshimura S, Sato M, Nagao T, Ono $\mathrm{H}$, Katoh $\mathrm{M}$ : Influence of di-(2-ethylhexyl)phthalate on fetal testicular development by oral administration to pregnant rats. J Toxicol Sci 2005, 30(3): I75-194.

50. Sjoberg P, Bondesson U, Kjellen L, Lindquist NG, Montin G, Ploen L: Kinetics of di-(2-ethylhexyl) phthalate in immature and mature rats and effect on testis. Acta Pharmacol Toxicol (Copenh) 1985, 56(I):30-37.

51. Oishi S: Reversibility of testicular atrophy induced by $\mathrm{Di}(2$ ethylhexyl) phthalate in rats. Environ Res 1985, 36(I): |60-169.
52. Kijima K, Toyosawa K, Yasuba M, Matsuoka N, Adachi T, Komiyama $M$, Mori C: Gene expression analysis of the rat testis after treatment with di(2-ethylhexyl) phthalate using cDNA microarray and real-time RT-PCR. Toxicol Appl Pharmacol 2004, 200(2): $103-110$.

53. Vo TT, Jung EM, Dang VH, Jung K, Baek J, Choi KC, Jeung EB: Differential Effects of Flutamide and Di-(2-ethylhexyl) phthalate on Male Reproductive Organs in a Rat Model. J Reprod Dev 2009, 55(4):400-4II.

54. Chen ML, Chen YC, Peng IW, Kang RL, Wu MP, Cheng PW, Shih PY, Lu LL, Yang CC, Pan CY: Ca2+ binding protein-I inhibits Ca2+ currents and exocytosis in bovine chromaffin cells. I Biomed Sci 2008, I 5(2): |69-|8|

55. Lee A, Westenbroek RE, Haeseleer F, Palczewski K, Scheuer T, Catterall WA: Differential modulation of $\mathbf{C a}(\mathbf{v}) 2.1$ channels by calmodulin and Ca2+-binding protein I. Nat Neurosci 2002, 5(3):210-217.

56. Aguilar-Mahecha A, Hales BF, Robaire B: Expression of stress response genes in germ cells during spermatogenesis. Biol Reprod 2001, 65(1): I19-127.

57. Pang AL, Taylor HC, Johnson W, Alexander S, Chen Y, Su YA, Li X, Ravindranath N, Dym M, Rennert OM, et al.: Identification of differentially expressed genes in mouse spermatogenesis. Androl 2003, 24(6):899-9II.

58. Okada M, Fujii M, Yamaga M, Sugimoto $H$, Sadano $H$, Osumi T, Kamata $\mathrm{H}$, Hirata $\mathrm{H}$, Yagisawa $\mathrm{H}$ : Carboxyl-terminal basic amino acids in the $X$ domain are essential for the nuclear import of phospholipase C delta I. Genes Cells 2002, 7(9):985-996.

59. Knox CD, Belous AE, Pierce JM, Wakata A, Nicoud IB, Anderson CD, Pinson CW, Chari RS: Novel role of phospholipase C-deltal: regulation of liver mitochondrial $\mathbf{C a 2 +}$ uptake. Am J Physiol Gastrointest Liver Physiol 2004, 287(3):G533-540.

60. Asemu G, Tappia PS, Dhalla NS: Identification of the changes in phospholipase $\mathbf{C}$ isozymes in ischemic-reperfused rat heart. Arch Biochem Biophys 2003, 4 I I (2): I 74- I82.

61. Thore S, Dyachok O, Tengholm A: Oscillations of phospholipase $\mathrm{C}$ activity triggered by depolarization and $\mathrm{Ca2+}$ influx in insulin-secreting cells. J Biol Chem 2004, 279(1 9): I 9396-1 9400.

62. Lai TH, Lin YF, Wu FC, Tsai YH: Follicle-stimulating hormoneinduced Galphah/phospholipase C-deltal signaling mediating a noncapacitative $\mathrm{Ca2}+$ influx through $\mathrm{T}$-type $\mathrm{Ca2+}$ channels in rat sertoli cells. Endocrinology 2008, I 49(3): | $03 \mid-1037$

63. Vicencio JM, Ibarra C, Estrada M, Chiong M, Soto D, Parra V, DiazAraya G, Jaimovich $E$, Lavandero $S$ : Testosterone induces an intracellular calcium increase by a nongenomic mechanism in cultured rat cardiac myocytes. Endocrinology 2006, |47(3): I386-1395.

64. Pedersen A, Skjong C, Shawlot W: Lim I is required for nephric duct extension and ureteric bud morphogenesis. Dev Biol 2005, 288(2):57|-58I.

65. Kobayashi A, Shawlot W, Kania A, Behringer RR: Requirement of Lim I for female reproductive tract development. Development 2004, I 3 I (3):539-549.

66. Horiba N, Masuda S, Takeuchi A, Saito H, Okuda M, Inui K: Gene expression variance based on random sequencing in rat remnant kidney. Kidney Int 2004, 66(I):29-45.

67. Song YS, Yang HJ, Song ES, Han DC, Moon C, Ku JH: Sexual function and quality of life in Korean women with chronic renal failure on hemodialysis: case-control study. Urology 2008, 7 I (2):243-246. 